\title{
MONITORING OF E-WASTE RECYCLING DATA
}

\section{Ljiljana Mitić*}

\section{Singidunum University,}

Belgrade, Serbia
Correspondence:

Ljiljana Mitić

e-mail:

ljiljana.mitic.20@singimail.rs

\begin{abstract}
:
Recycling of electronic and electrical waste (hereinafter E-waste) is becoming an increasingly important topic in Serbia, as well as in the world. Monitoring data on the quantities and types of e-waste that is recycled is important for recycling centers, but also for the Environmental Protection Agency and the Ministry of Environmental Protection. Regardless of the importance of this data in Serbia, a special program has not yet been developed to monitor and uniquely present this data. In the absence of a single program, recycling centers use a variety of accounting programs as well as Microsoft Office applications (mostly Excel).

Based on the data they generate in their programs, all recycling centers compile certain statistical and annual reports on waste movements at the end of the year. They also have the obligation of quarterly, monthly and daily reporting for certain types of E-waste.
\end{abstract}

Keywords:

Data monitoring, E-waste movement, E-waste, softver.

\section{INTRODUCTION}

In Serbia, as well as in the world in recent years, there is a growing trend of recycling of E-waste due to the faster obsolescence of electrical and electronic devices. The increase in recycling is good news, but larger quantities of recycled waste mean that it is becoming increasingly difficult to monitor them. In Serbia, a single software has not yet been developed to monitor the movement of waste, as well as the amount of collected and recycled E-waste. As a program that serves this purpose alone does not exist, recycling companies are forced to use and develop their own tools to track this data.

According to the Law on Waste Management, all recycling centers are obliged to report any movement of waste to the Environmental Protection Agency, as well as to confirm the movement of waste, confirming its movement, specifying data on the amount and type of waste, mode of transport and the like. 
These data are submitted by recyclers to the Agency electronically, as well as physically to the address of the Agency within 15 days from the end of the movement of waste. In order not to leave something out, recycling centers use various applications and software in which they enter data on the quantities of waste collected, treated and delivered. The most commonly used application for generating and tracking data is Microsoft Excel. In Excel, various tables are formed with precise data on the planned waste collection for the next week, on the type and amount of waste collected, treated waste, recyclables, daily reports, disposed waste and the like. In order to make data tracking as easy as possible, the bookkeeping programs that the company owns are also used.

These data are also entered in these programs and it is possible to obtain numerous reports based on them. Accepted Quantities of collected waste can be entered via Calculations, and quantities of treated waste using Requirements and Work Orders stating the result of recycling (recycling). Based on the entry of these data, it is possible to check the current waste warehouses, as well as the condition in all warehouses.

\section{MONITORING OF E-WASTE RECYCLING DATA}

E-waste recycling has made significant progress in Serbia in recent years. Recycled quantities are growing, and the number of Operators dealing with E-waste treatment is growing. Therefore, there is a greater need for both the state and the Operators themselves to monitor data on E-waste recycling. E-waste recycling companies have a legal obligation to notify each waste movement to the Environmental Protection Agency 48 hours in advance, as well as to confirm the movement when it is completed and to submit documents on waste movement to the Agency by mail. It is very important that the data is accurate, precise and delivered on time. In the computer age, companies use a variety of programs and applications to track all the necessary data and reduce the possibility of errors. Unfortunately, specialized software has not yet been developed in Serbia to serve this purpose, so recyclers use existing business software. By using business software to track the entire business, companies can generate various data that serve as a basis for monitoring business performance from year to year, as well as for various statistical reports. When it comes to recycling, one of the important parameters for monitoring business success is the amount of waste taken over. Quantities of collected waste are observed separately for each class of waste. Another criterion by which the taken over E-waste is classified are the channels from which the waste is taken over. Recyclers, i.e. recycling employees, enter individual Calculations in the program, based on the documentation they receive after each waste movement. On that occasion, they enter the quantity and type of arrived and sorted waste, the date of collection, the data of the waste carrier and the data of the owner of the waste. Also, at the end of each shift, data on the amount and type of E-waste that is recycled and the amount and type of recycled waste are entered. Precise quantities of recyclables obtained (recycling result) are entered for each individual type of E-waste (so that it is possible after a certain time, to predict based on the amount and type of waste and the value related to recyclables). Based on the entered data, the program at any time provides information on the exact amount of waste collected, waste in the warehouse, as well as recyclables that can be resold and those that need to be disposed of.

Depending on the requirements entered, business software offers a large number of tabular reports. It is necessary to determine the time period for which the report is needed and define which data we want to consider in the report. So we can choose a specific category of E-waste or all downloaded E-waste. In addition, we can designate only one supplier or group suppliers, for example according to their location or according to whether the collection of E-waste is their primary activity or they are obliged by law to return waste from their own business for recycling, or in question. individuals and the like. The program also includes so-called readymade, ie standard reports, which are often used and in which everything is defined in advance and it is only necessary to enter the period for which we need a report. These reports make it easy to track business and compare data at different time intervals.

The following is a report in the form of a table, showing the quantities of E-waste taken in a given year, sorted by waste classes, provided by one such program (Table 1). 


\begin{tabular}{|c|c|c|}
\hline Class & Quantity & $\begin{array}{l}\text { Percentage } \\
\text { of } \\
\text { participation }\end{array}$ \\
\hline $\begin{array}{l}\text { Monitoring and control } \\
\text { instruments }\end{array}$ & 4,367,918.00 & $17.03 \%$ \\
\hline $\begin{array}{l}\text { Toys and equipment for } \\
\text { recreation and sports }\end{array}$ & 314.00 & $0.00 \%$ \\
\hline Automats & $67,748.00$ & $0.44 \%$ \\
\hline CRT monitors & $243,366.00$ & $1.99 \%$ \\
\hline EE tools & $2,710,686.00$ & $12.92 \%$ \\
\hline $\begin{array}{l}\text { IT and telecommunications } \\
\text { equipment }\end{array}$ & $759,341.00$ & $4.31 \%$ \\
\hline Small home appliances & $168,096.00$ & $0.72 \%$ \\
\hline Medical assistive devices & $28,483.00$ & $0.10 \%$ \\
\hline Consumer equipment & $73,907.00$ & $0.48 \%$ \\
\hline Lighting equipment & $83,919.00$ & $0.15 \%$ \\
\hline Other TV sets & $104,189.00$ & $0.38 \%$ \\
\hline $\begin{array}{l}\text { Air conditioners and } \\
\text { refrigeration equipment }\end{array}$ & $3,874,883.00$ & $27.97 \%$ \\
\hline CRT TVs & $2,853,608.00$ & $22.15 \%$ \\
\hline Heating devices & $22,323.00$ & $0.16 \%$ \\
\hline Large home appliances & $809,198.00$ & $11.21 \%$ \\
\hline In total & $16,437,977.00$ & $100.00 \%$ \\
\hline
\end{tabular}

Table 1 - Amount of waste taken over in 2020

The data shown in Table 1 - Amount of waste taken over in 2020, represent one standard report in which the data are classified according to a certain criterion (in this case it is the $\mathrm{E}$-waste class) for a time interval of one year with a percentage share in the total amount. The percentage of participation of individual classes of E-waste in the total amount of collected and recycled waste is very important.

Based on this percentage and data on the obtained recyclates (quantity of recyclates and their quality), we can conclude which is the optimal combination of $\mathrm{E}$ waste, i.e. which combination of E-waste during recycling gives the highest quality recyclables.

In the same way, the data related to recyclables, quantities and types of E-waste that is in the temporary storage are presented, but the time interval is not determined, but the exact date for which the report is needed. Reports related to the quantities of recycled E-waste require the determination of the period for which the report is required and look similar. Based on these data, it is possible to make decisions on a daily basis about the type of E-waste that will be recycled or, for example, about the sale of certain recyclables such as iron, copper, glass, plastic and the like.

There are many such reports, and it is possible to modify the requirements according to current needs. Modification of requirements is done if some specific data is needed, if we want to determine, for example, productivity in certain conditions or the quality of recyclables obtained by processing a particular waste, from a new supplier or E-waste that we have not treated so far (some specific tools, etc.).

By entering data, it is possible to monitor the operation of the recycling plant, i.e. the exact time of downtime. This provides the ability to analyze the causes of failures.

The following is another standard report, which is very often used. This is a report that monitors and compares the planned and actual quantities of collected E-waste. These data can be viewed on a daily, weekly, monthly, quarterly, semi-annual and annual basis. Monthly and annual reports are most often used. These data can be observed for all collected electrical and electronic waste, or for a certain class of waste. By selecting the appropriate parameters, the desired report is obtained.

\begin{tabular}{lccc}
\hline Month & Realization & Plan & \%Realizations \\
\hline $2021-1$ & $164,662.00$ & $161,000.00$ & 102.3 \\
\hline $2021-2$ & $301,883.00$ & $250,500.00$ & 120.5 \\
\hline $2021-3$ & $416,574.00$ & $312,500.00$ & 133.3 \\
\hline $2021-4$ & $398,192.00$ & $341,500.00$ & 116.6 \\
\hline $2021-5$ & $54,922.00$ & $341,500.00$ & 16.1 \\
\hline $2021-6$ & & $351,000.00$ & \\
\hline $2021-7$ & & $351,000.00$ & \\
\hline $2021-8$ & & $351,000.00$ & \\
\hline $2021-9$ & & $351,000.00$ & \\
\hline $2021-10$ & & $341,500.00$ & \\
\hline $2021-11$ & & $341,500.00$ & \\
\hline $2021-12$ & & $306,000.00$ & \\
\hline Ukupno & $1,336,233.00$ & $3,800,000.00$ & 35.2 \\
\hline
\end{tabular}

Table 2 - Plan and realization of collected E-waste in 2021Advantages and disadvantages of existing data monitoring programs 
Tracking data on recycled E-waste using existing commercial software has its advantages and disadvantages. As already mentioned, these are general accounting programs for comprehensive business monitoring. Their main advantage is that they are easy to use, so no additional training of employees is required to use it. These programs can be used by anyone who has been involved in bookkeeping or has been in contact with business software. Generally, companies that offer business software also offer free training to employees on how to use the software and support when using it. The advantage of these programs is that all data is in one place. [1] So that the financial data can be easily compared with the data on the movement of waste, or for example the data on the treated quantities can be compared with the data on recycled materials and in that way it is possible to easily detect errors if they occur. Centralized data storage also provides the possibility of various financial reports, makes it easier to monitor the productivity of workers in different conditions and the like. From a financial point of view, the use of standard business monitoring programs is a cheaper option than developing specialized software for the needs of recycling centers.

What appears to be a disadvantage is the fact that these programs do not specialize in the recycling business, so additional use of Excel is necessary, for example, to avoid mistakes. In such programs, it is not possible to monitor the entire movement of waste, from the moment of announcing the movement to the Environmental Protection Agency to the moment of storage and confirmation of movement. There is no option to confirm the return of certified Waste Movement Documents that recyclers are required to keep and submit to the Agency under the Law on Waste Management. [2] Documents on the movement of waste are still submitted to the Agency, physically, by mail, which requires additional costs, both financial and unnecessary spending of paper (when printing documents).

These programs are diverse, there are many of them, so the reports of different recycling centers are not unified, which reduces the visibility of the reports and their comparison. Another problem is that these programs are not synchronized with the software of the Environmental Protection Agency, so that all data on the Agency's website are typed, ie data are first extracted from its own program, and then entered on the website. That way, there is a high chance that an error will occur, that something will be missed or that the wrong information will be entered. If an error occurs, some data can be changed, while for some it is necessary to contact the Agency. These are just some of the disadvantages of using non-specialized software.

\subsection{POSSIBLE DEVELOPMENT OF A RECYCLING DATA MONITORING PROGRAM}

Monitoring data on the amount of recycled E-waste is of great importance not only for companies engaged in this activity, but also for the state itself. Namely, in order to develop its strategy, the state must have accurate and precise data on the quantities of collected and recycled waste. Also, based on these data, the state determines and allocates subsidies to recyclers, which is another reason for these data to be reliable. First of all, it is necessary to develop a program that would monitor the entire cycle of waste movement, from the very beginning (announcement of waste movement to the Agency) to the end (confirmation of movement, exact quantities of transported waste, data on the carrier, etc.). It would be good for the program to be used by all companies that deal with this activity, so that the reports would be unique.

One of the possible directions of program development is the use of QR code. By using a QR code on documents on the movement of waste, it would be possible to enter data into the program by simply reading it. In this way, important data such as the amount of waste, the date of movement of the waste, the conveyor and the like would be entered automatically.

Another possibility for development is for the program to be harmonized with the program on the website of the Environmental Protection Agency so that the data can be automatically submitted to the Agency by simply exporting data from the company's program. This would significantly reduce the possibility of errors when entering data and would reduce the time required to enter data. All of the above would increase labor productivity. It would be good to improve the Agency's software in terms of developing opportunities for document entry and create a centralized database of all documents entered in the field of e-waste recycling. [3, p. 34]

Taking into account the fact that recyclers are obliged to keep daily records of waste (to fill in DEO forms), as well as annual reports on waste (GIO forms), the program should generate these reports (in the form of prescribed forms) based on data are entered daily.

E-waste recycling is an important topic at the global level as well. However, there is no single program or single report in the world that could easily compare 
recycling data from different countries. Quality and comparable data are needed in order to define a clear waste management policy at the global level, to develop E-waste statistics, as well as to reduce illegal trade in this area. [4] [5, p. 18]

\section{CONCLUSION}

Based on all the above, we can conclude that monitoring data in the field of recycling of electrical and electronic waste is difficult and underdeveloped. This stems from the fact that the recycling of E-waste itself, as well as the awareness of citizens and the state about the importance of recycling and the circular economy, is still not sufficiently developed. A program that would be used by recycling companies and that would be synchronized with the program of the Environmental Protection Agency has not been developed yet.

E-waste recycling companies are forced to use existing business monitoring software, which is not specialized, and to adapt it to their own needs. The main advantage is that there is no need to further train employees to use the program and that no additional costs are required. It is also important that all the data is in one place, so it is easy to compare them. What appears to be the main drawback is that it is not possible to monitor the entire flow of waste, but it is necessary to use additional applications and create tables and graphs for comprehensive data monitoring and error avoidance.

There is a strong need to develop a single specialized software that would be used by all operators involved in the collection and recycling of electrical and electronic waste. Such a program should make it easier to monitor and publish E-waste recycling data. The development of a specialized program would speed up and facilitate the submission of data to the Environmental Protection Agency and monitor the movement of waste from the announcement of the movement to the very end of the movement. All reports related to the recycling of electrical and electronic devices would be presented in the same way, which would contribute to better visibility.

\section{REFERENCESS}

[1] „Logik,“ Logik poslovna rešenja d.o.o., https://www. logik.rs/proizvodi/firma/\#. [acessed 2804 2021].

[2] Zakon o upravljanju otpadom, Beograd: Službeni glasnik Republike Srbije, 36/2009, 88/2010, 14/2016, 95/2018.

[3] N. Pokimica, K. Nedeljković Bunardžić, S. Krstović, Analiza stanja upravljanja električnim i elektronskim otpadom u Republici Srbiji, Beograd: NALED Nacionalna alijansa za lokalni ekonomski razvoj, 2018.

[4] I. Todorović, „Balkan green energy news,“24 072020. https://balkangreenenergynews.com/rs/e-otpaduglavnom-ide-na-deponije-i-zagaduje-umesto-dase-reciklira/. [acessed 2505 2021].

[5] D. Vučković, Model održivog upravljanja električnim i elektronskim otpadom u Srbiji, doktorska disertacija, Novi Sad: Fakultet za ekonomiju i inženjerski menadžment, 2019. 